\title{
CHOROIDAL HAEMANGIO-ENDOTHELIOMA*
}

\author{
BY \\ ARTHUR LISTER AND GWYN MORGAN \\ Moorfields Eye Hospital, and Department of Pathology, Institute of Ophthalmology, \\ University of London
}

HAEMANGIO-ENDOTHELIOMATA have not been reported previously in the choroid, although such tumours have been described in the orbit (Stout, 1943; Forrest, 1949; Reese, 1951; Icken, 1955; Hogan and Zimmerman, 1962), in the lid (Stout, 1943; Reese, 1951), and in the retina (Nastri and Basile, 1939; Souders, 1949).

The usual type of angiomatous tumours of the choroid, which are cavernous in structure, have been described on numerous occasions (DukeElder, 1940; Godtfredsen, 1947; Rosen, 1950; Reese, 1951; Jones and Cleasby, 1959; Maclean and Maumenee, 1959; Hogan and Zimmerman, 1962). The histological appearance is that of dilated vascular channels filled with erythrocytes and separated by a minimal amount of stromal tissue. The earliest descriptions of these angiomata were made by Panas and Remy (1879) and Milles (1884). Cushing and Bailey (1928) thought them to be angiomatous malformations, and Bergstrand, Olivecrona, and Tönnis (1936) described them as telangiectatic types of angioma venosum racemosum. Recent articles support the previous theories that these tumours are not true neoplasms but congenital malformations of choroidal vessels.

On the other hand haemangio-endotheliomata probably represent true neoplasms and are composed of vascular channels and endothelial cells in excess of the number required to line them. There is, in addition, a characteristic reticulin network enclosing the endothelial cells. In the orbit, these tumours resemble the vascular buds of endothelial cells in the embryo before the development of vessels. In infants and children they are nearly always benign, but Carelli and Cangelosi (1948) described a malignant form in a girl of 11 years. On the other hand, haemangio-endotheliomata in adults are nearly always malignant, and probably arise de novo.

* Received for publication August 2, 1962. 


\section{Case Report}

A male child aged 3 months was thought by his foster parents to be blind. An ophthalmic surgeon (Mr. J. Whitwell) found that the child could see but that the red reflex in the right fundus was obscured in certain places. Examination under anaesthesia showed a retinal detachment on the temporal side of the right eye.

At the age of 4 months the child was admitted to Moorfields Eye Hospital and it appeared that his sight was defective because he did not seem to be as attentive to what was happening in front of him as a normal child of his age. However, the pupils reacted equally to light.

Ophthalmological Examination under Anaesthesia with Pupils Dilated.-The left eye was normal. The right eye showed a detachment of the retina on the temporal half of the fundus; this looked simple in type although no hole could be found and there was a sharper edge to the detachment than usual. Transillumination was clear, except for a curious ring-like shadow in the centre of the detachment.

Opinion was divided as to whether the detachment was simple or otherwise. $X$-ray examination for signs of calcification within the eye (which would suggest a retinoblastoma) was normal. After 3 weeks there was no change in the detachment and it was decided to try to aspirate subretinal fluid and to inject saline into the vitreous with the idea of proving whether or not the detachment was solid or fluid in whole or in part. Should it prove to be more or less solid, the most likely reason would be a retinoblastoma exophytum, and it was thought that even if there was an escape of retinoblastoma cells into the orbit, these would be sensitive to radiotherapy.

However, attempts at aspiration with several sizes of needle proved fruitless until a very large bore needle was used, when a dribble of semi-liquid material came from the site of the puncture. This liquid was placed on a slide and sent to the Institute of Ophthalmology where it was examined by Professor Ashton, the patient being kept under an anaesthetic meanwhile.

Laboratory Investigation.-Prof. Ashton reported by telephone that the pathology was obviously that of a tumour and that, although there were no rosettes, it was probably a retinoblastoma.

Surgery.-The eye was therefore enucleated.

Comment.-In retrospect it is difficult to conceive any course of treatment other than that adopted. Calcification is a common feature of retinoblastoma and radiological evidence can be found in 75 per cent. of cases (Reese, 1951), rosettes being present in about 50 per cent. of cases. The absence of these features in this case was suggestive but was not conclusive evidence of some other condition, and on clinical grounds retinoblastoma remained the probable diagnosis.

\section{Pathological Features}

Needle Aspirate.-Smears stained with haematoxylin and eosin showed sheets of pale basophilic round and oval cells. There was little evidence of pleomorphism and mitotic figures were absent. No rosettes or vessels were seen (Fig. 1, opposite).

The histological findings were indefinite, but it was thought that the lesion was a neoplasm and that the most likely diagnosis was retinoblastoma.

Enucleated Eye.-There was an ovoid, buff-coloured, non-pigmented choroidal mass on the temporal side of the globe, posterior to the equator and apparently confined to the choroid (Fig. 2, opposite). 


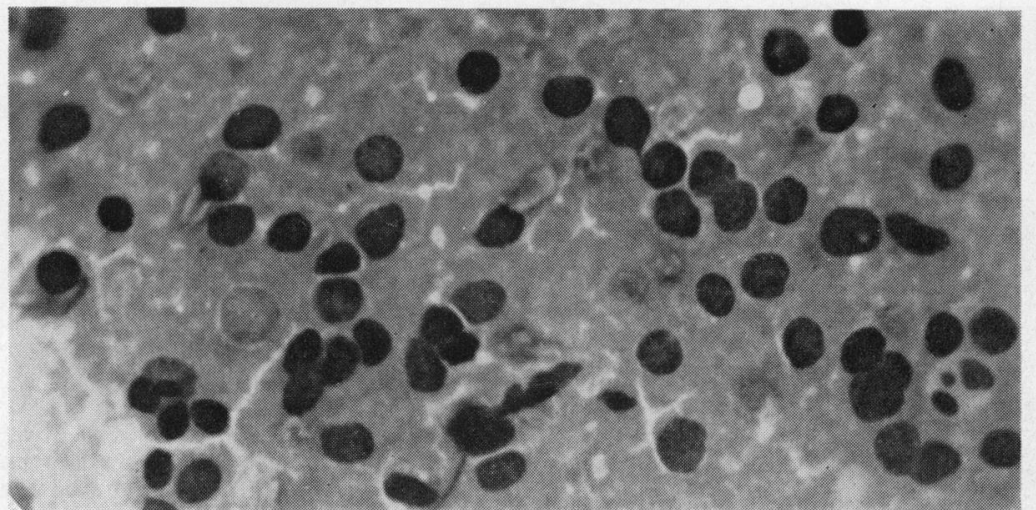

Fig. 1.-Smear of needle aspirate, showing round and oval cells but no rosettes. Haematoxylin and eosin. $\times 575$.

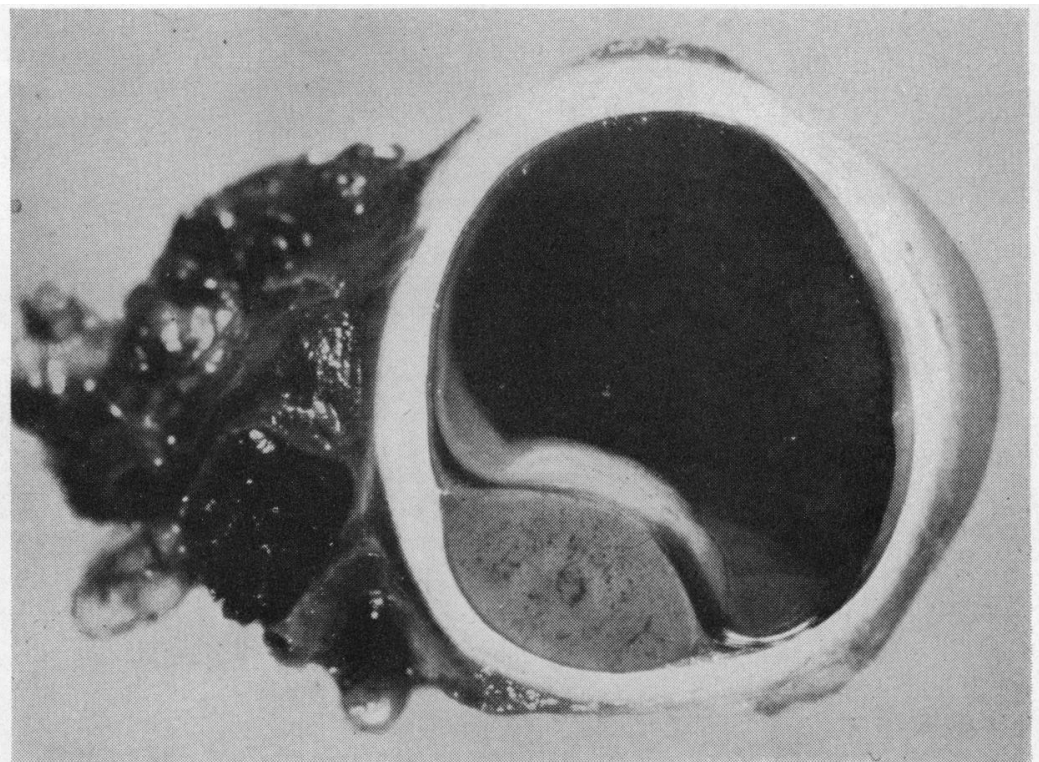

Fig. 2.-Opened eye, showing choroidal tumour posterior to the equator causing overlying retinal detachment. $\times 3 \cdot 8$.

Histological examination showed a haemangio-endothelioma composed of vascular channels and large numbers of embryonic endothelial cells in excess of the number required to line these channels. These cells were of fairly uniform size and shape with no evidence of mitotic activity (Fig. $3 a, b$, overleaf).

The tumour was confined to the choroid and had produced detachment of the overlying retina, which showed reactive gliosis and also a small area of fibrosis due to a local stimulation by pigment from the pigment layer. A Wilder stain for 


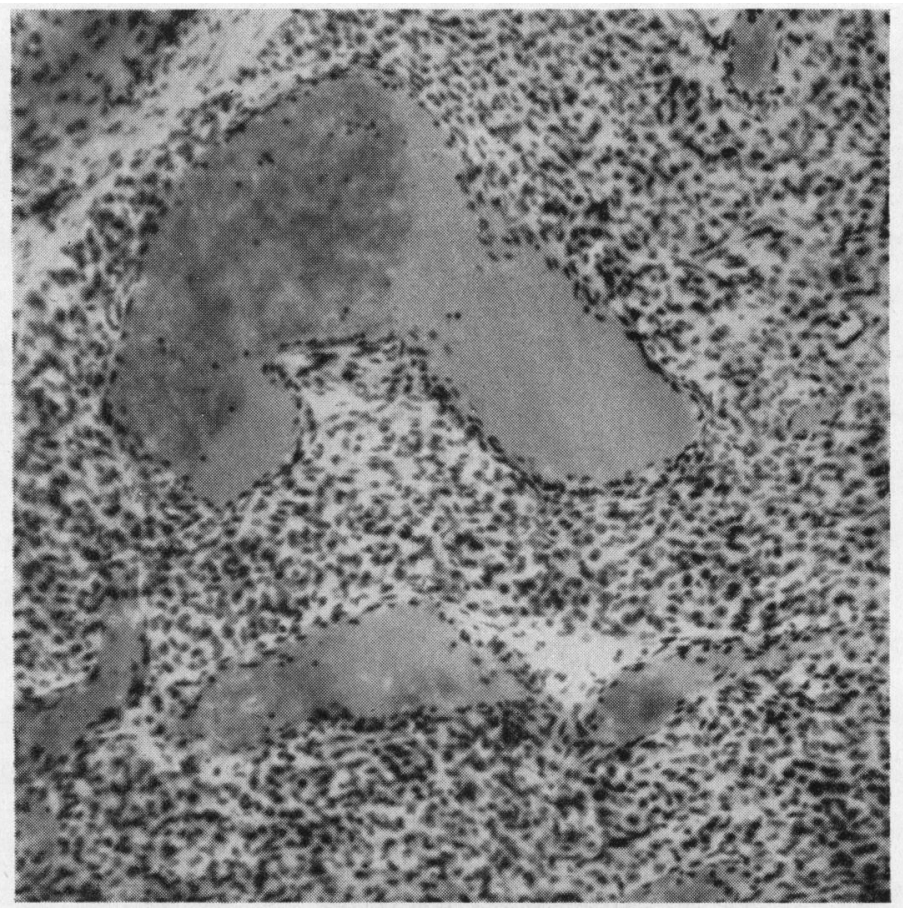

FIG. 3(a).-Section of tumour, showing vascular channels and endothelial cells in excess of the number required to line these channels. Haematoxylin and eosin. $\times 120$.

Fig. 3(b).-High-power view of Fig. 3(a). $\times 575$.

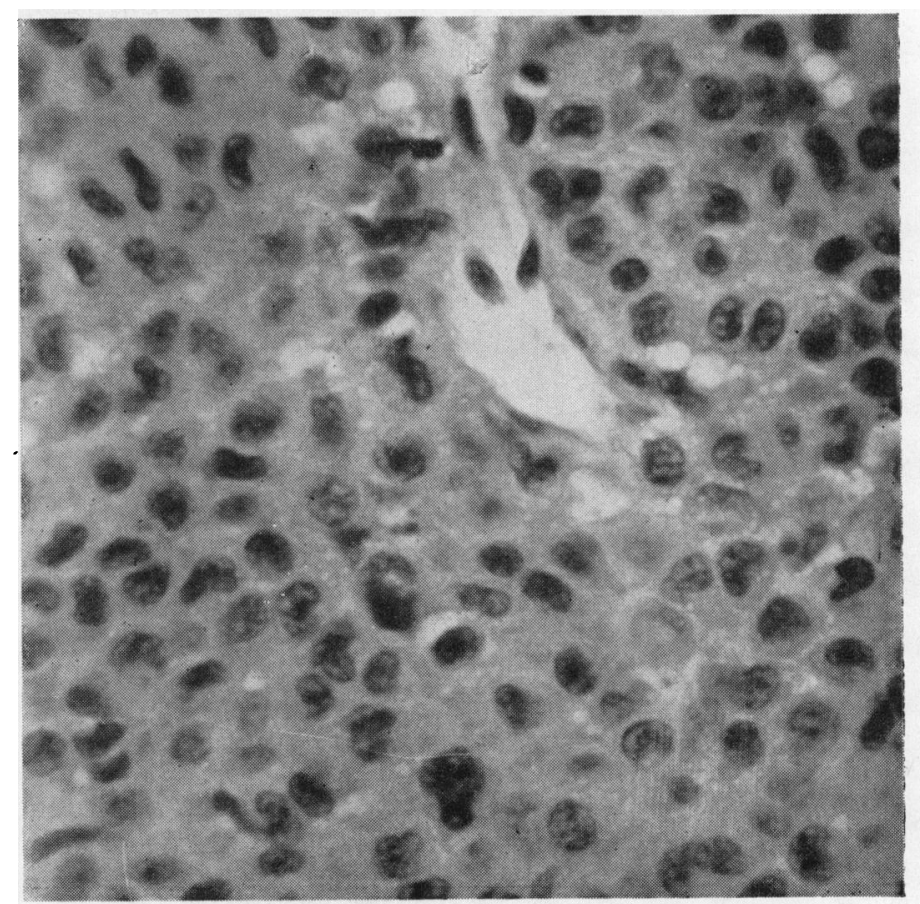


reticulin showed the characteristic honey-comb network of this neoplasm and proliferating endothelial cells completely surrounded by reticulin throughout the tumour (Fig. $4 a, b$ ). Frozen sections of the neoplasm were stained for fat but none was detected.

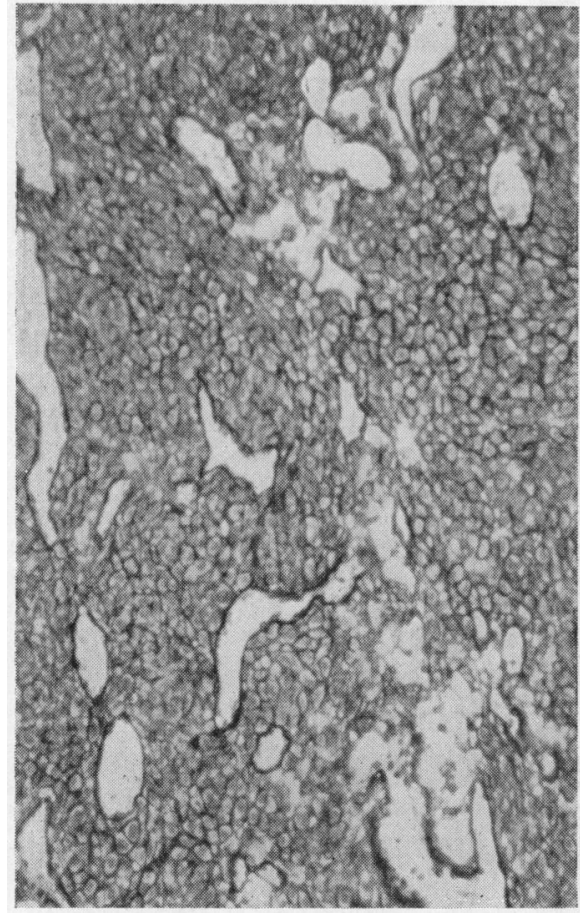

FIG. 4(a).-Section of tumour, showing characteristic honey-comb reticulin network. Wilder. $\times 120$.

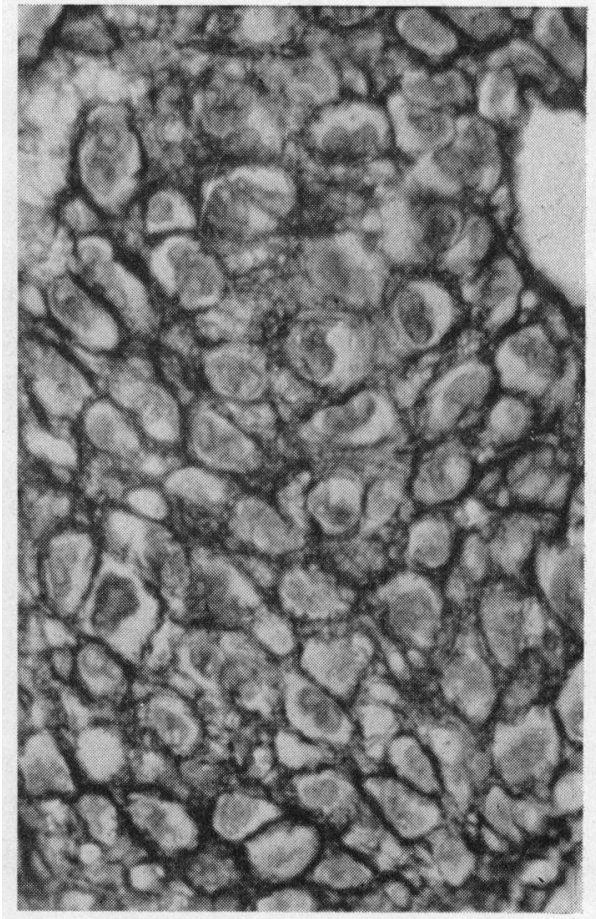

FIG. 4(b).-High-power view of Fig. 4(a), showing details of reticulin structure and proliferating endothelial cells completely enclosed by reticulin. $\times 575$.

Diagnosis. - In arriving at the diagnosis of haemangio-endothelioma, the possibility that this tumour was a melanoma had to be considered. The general histological appearance was unlike that of a melanoma and the cells in no way resembled those seen in this neoplasm. Furthermore, the vascular component was part of the neoplasm, and not an incidental association. The reticulin pattern finally confirmed the diagnosis, because, although reticulin is found in melanotic tumours of the choroid, the pattern does not resemble the characteristic honey-comb network surrounding endothelial cells which is a constant feature of haemangio-endotheliomata.

\section{Discussion}

As previously indicated in the introduction to this article, cavernous angiomata of the choroid are considered to be congenital abnormalities, and the evidence in favour of this contention is overwhelming. First, angiomatous 
tumours merge imperceptibly with the normal vasculature of the choroid, and this is a well-known feature of congenital tumours in general. Secondly, when these angiomata are associated with similar tumours of the face and meninges as in the Sturge-Weber syndrome, the facial lesions are often present at birth and in any case by 6 months of age in 95 per cent. of cases. Thirdly, Streeter (1918) showed that developmentally the blood supplies to the choroid, the meninges, and the face were derived from the same source. The multicentric origin of these tumours, and the fact that the cerebral variety may enlarge rapidly through haemorrhage or cyst formation has been wrongly construed as a sign of neoplastic growth.

On the other hand, the histogenesis of haemangio-endotheliomata is less well defined. It is probably a true neoplasm having its origin in endothelial cells. Unlike the cavernous angiomata, which may undergo spontaneous regression, the haemangio-endothelioma is often malignant, especially in adults. Furthermore, although it may have a benign histological appearance, e.g. in the lid or orbit, it may be locally invasive and may recur following excision. Is there any evidence that this tumour may be a congenital abnormality? Ashton, Ward, and Serpell (1954) were able to stimulate new retinal vessel formation in kittens by subjecting them to atmospheres which amounted to relative anoxia. Some of the vasoformative mesenchymal tissue which was formed bears some resemblance to the histological features of the haemangio-endothelioma. It would be interesting to know if this tumour could be reproduced in the choroid by some as yet unknown stimulus, but our knowledge of the natural history of these tumours in tissues elsewhere in the body would indicate their neoplastic nature rather than some congenital malformation of this kind.

\section{Summary}

A case of haemangio-endothelioma of the choroid in a child of 3 months is reported. This lesion, while known to occur in the orbit, lid, and retina, has not, hitherto, been reported in the choroid. It caused a detachment of the retina which led to removal of the eye for suspected retinoblastoma exophytum. Histological examination showed that the tumour was confined to the choroid and consisted of vascular channels and large numbers of embryonic endothelial cells contained in a reticulin network. While cavernous angiomata are regarded as congenital anomalies, haemangio-endotheliomata are considered to be true neoplasms which may be benign or malignant-in this case benign.

We should like to thank Prof. Norman Ashton for his invaluable advice, and we are grateful to Miss E. FitzGerald for secretarial help, and to Mr. F. H. Vincer and Mr. V. J. Elwood for their technical assistance in the preparation of sections and microphotographs.

\section{REFERENCES}

Ashton, N., WARD, B., and Serpell, G. (1954). Brit. J. Ophthal., 38, 397.

Bergstrand, H., OLIVECRONA, H., and TöNNIS, W. (1936)." "Gefässmissbildungen und Gefässgeschwülste des Gehirns". Thieme, Leipzig. 
Carelli, P. V., and Cangelosi, J. P. (1948). Amer. J. Ophthal., 31, 453.

Cushing, H., and Bailey, P. (1928). "Tumors arising from the Blood-Vessels of the Brain". Thomas, Springfield, Ill.

Duke-Elder, S. (1940). "Text-book of Ophthalmology", vol. 3, p. 2458. Kimpton, London.

Forrest, A. W. (1949). Arch. Ophthal. (Chicago), 41, 198.

GODFREDSEN, E. (1947). Acta ophthal. (Kbh), 25, 279.

Hogan, M. J., and Zimmerman, L. E. (1962). "Ophthalmic Pathology", pp. 741, 431. Saunders, Philadelphia.

ICKeN, E. (1955). Klin. Mbl. Augenheilk., 127, 472.

Jones, I. S., and Cleasby, G. W. (1959). Amer. J. Ophthal., 48, 612.

Maclean, A. L., and Maumenee, A. (1959). Trans. Amer. ophthal. Soc., 57, 171.

Millers, W. J. (1884). Trans. ophthal. Soc. U.K., 4, 168.

Nastri, F., and Basile, G. (1939). Boll. Oculist., 18, 797.

Panas, F., and Remy, A. (1879). "Anatomie pathologique de l'oeil". Delahaye, Paris.

REESE, A. B. (1951). "Tumors of the Eye", pp. 73, 92, 350. Hoeber, New York.

Rosen, E. (1950). Ophthalmologica (Basel), 130, 127.

Souders, B. (1949). Arch. Ophthal. (Chicago), 41, 178.

Stout, A. P. (1943). Ann. Surg., 118, 445.

Streeter, G. L. (1918). "Contributions to Embryology", vol. 8, p. 5 [No. 24]. Carnegie Institution of Washington, Publ. No. 271. 